\title{
Environmental impact assessment of the employment of methane-run buses: a case study analysis for Padua, Italy
}

\author{
P. Amrusch ${ }^{1}$, A. Tortella ${ }^{2}$, A. Morini (retired) $)^{2} \&$ F. Wirl ${ }^{1}$ \\ ${ }^{1}$ University of Vienna, Austria \\ ${ }^{2}$ Department of Industrial Engineering, University of Padua, Italy
}

\begin{abstract}
This paper analyzes the impact of new fuel technologies in connection with emission standards on public transport emissions as a basis for traffic planner's decision making in Padua (Italy) in the period of time before construction works for the introduction of a tram network was planned. After analyzing the public and private transport system in the most critical urban environment of Padua, first, an engineering model is constructed to technically calculate the environmental impact of methane-run buses (Euro IV) in comparison to buses running on other types of fuel. Afterwards, similar results are obtained by using (pseudo) data in reduced form relations. Finally, the quantification of transport externalities is discussed, whereby different methods of environmental valuation are pointed out with special emphasis on health issues. The results of this study will be used as a basis for future comparative research assessing the social and environmental impact of public policy measures that have been implemented.

Keywords: transport externalities, public transport policies, pseudo data approach, particulate matters, European emission standards.
\end{abstract}

\section{Introduction}

The worsening of quality of life and the more and more frequent appearance of diseases due to air pollution, specifically particulate matters, even in mid-size cities requires a detailed evaluation of the ecological and economic impacts of public transport systems. Such systems are indeed an important aspect of public policy as they enjoy superior predictability in comparison to private transport, and they can affect private transport internally in terms of substitutability. Moreover, 
the realization of more sustainable transport calls for the development of a more efficient public transport system as well as the adoption of new technologies for public vehicles with low environmental impact. The first option aims at the reduction of private car traffic by ensuring a good level of accessibility, service and comfort, mainly in urban areas surrounding the city centers, in which private traffic is often limited by municipality regulations. This situation is particularly critical in some mid-size Italian cities where the inadequacy of the road system around the urban area concentrates traffic along very few arterials. The second option proposes the introduction of innovative transport solutions which assure very low emissions and reduced noise and vibrations with acceptable investment and operating costs. First of all, a more intensive substitution with greener fuels (biodiesel, methane, LPG, etc.) can be applied to buses propelled only by an internal combustion engine (ICE), therefore enabling reduced emissions with limited rise in costs. Otherwise the use of hybrid and pure electric vehicles can be considered. In particular, the pure electric vehicles (ZEV) supplied by an external overhead wire (tramway, trolley-bus, intermediate rubber tired systems with guided running mode) or by on-board batteries can fulfill the zero emission targets. However, the former require a high transport demand to cover the considerable investment and operating expenditure, and they are often critical to integrate into the urban environment; the latter have limitations related to the present status of commercial batteries, as regards both the operating range and the passenger capacity. The utilization of ZEV buses supplied by fuel cells (FCs) seems to be a very promising solution as regards both the operating range and the efficiency, if the FCs are supported with on-board energy storage devices; however, at present the costs of such technology and of the hydrogen supply infrastructure seem to be still too high and the long-term reliability of the FCs is difficult to predict. In Padua a tram network has been in service for a few years providing a connection between the center with certain outlying areas. The tram operation has led to an appreciable improvement in accessibility and a reduction of private cars circulating in the downtown area and its surroundings. However, its extension to other urban areas planned at the time of its construction is still under discussion, because of the high infrastructural impact and expenditures. In particular, there is one residential area near the Padua center (Chiesanuova) showing critical emission levels harming the health of inhabitants, where the tramline will not be implemented; consequently, alternative solutions for improving the efficiency of public transport in this area have to be considered, in particular to improve air quality for residents. Contrary to other residential areas of Padua, Chiesanuova is characterized by high traffic densities and a well-developed public transport system of bus lines, provided with vehicles ranging from Euro II to Euro IV emission standards. In this context, the paper attempts to show the degree of environmental and potential social improvements in Chiesanuova by replacing all gasoline and diesel-run buses (Euro II, III) by methane run buses (Euro IV).

In the introductory section, the transport situation of the north Italian city of Padua in 2006 with particular reference to the residential area of Chiesanuova is investigated. First, the estimations of the regional environmental agency (ARPAV [1]) regarding the traffic densities and the specific emissions are examined. 
Afterwards, starting from the data provided by municipality of Padua and by the main public transportation company Azienda Padova Servizi (APS [2]), the relevant traffic emissions caused by public transport are evaluated by using the software program COPERT III [3], analyzing different transport scenarios. The generated data are integrated in a pseudo data approach, i.e., using engineering representations, regressions map out a reduced form between technical variables and emissions (Griffin [4, 5]), allowing for a comparison of results obtained by the technical model and that of the pseudo data approach. Moreover, results are used to made reference to the possible evaluation of the social costs based on the study conducted by the WHO [6], discussing aspects of monetary quantification of transport externalities associated with other local studies.

\section{Background information}

In recent years, the city of Padua was repeatedly interested in pollution problems, mainly because the level of particulate matters (PM) exceeded the health limits several days every week (WHO [6]). The introduction of the new public transport system Metrotram in March 2007 propelled by electric motors, has led to a considerable improvement of the transport service in the urban context, substantially confirming the preliminary evaluations developed by Andriollo et al. [7]. However, some areas not immediately supplied by this service require a more detailed evaluation of the transport modes and of the public transportation capacity in terms of both the replacement of private cars and the improvement of the environmental conditions by introducing less pollutant vehicles. From this point of view Chiesanuova is a very critical zone, located to the west of the Padua city center: even if it is a well-served area in terms of public transport; it is characterized by high traffic densities. For instance, the number of vehicles measured by sensors placed in the roadway is about 200,000. Furthermore, in comparison to other areas near the Padua center, the traffic includes different types of vehicles, such as urban buses, motorcycles, private cars, as well as heavy commercial vehicles (HCV) and light commercial vehicles (LCV) (Environmental Agency of Veneto (ARPAV) [1]). Although passenger car traffic predominates ( $85 \%$ of the average number of vehicles for each category ARPAV [1]), in the investigated area the public transport system covers a non-negligible part of the operating vehicles. In this context, substitutability between public and private transport plays a crucial role. As displayed by Table 1, the number of private cars decreases in streets characterized by high densities of urban buses. On the other hand, the number of motorcycles is positively correlated with the number of urban buses, presumably due to the traffic rules (as, e.g. one-way streets which are bidirectional for buses). Further analysis focuses on the street sections mainly characterized by public transport: Figure 1 illustrates the three street sections investigated in Chiesanuova, denoted by A; B; $\mathrm{C}$ the main data on which are reported in Table 2. Section A (located outside of the historical center) consists of two different bus routes, number 10 and 6; sections $\mathrm{B}$ and $\mathrm{C}$ (inside and close to the historical center); where the bus routes number 10, 5, 6, 9 and number 5, 6, 9 
434 Ecosystems and Sustainable Development X

are situated, respectively. The total number of the regularly scheduled urban public transit bus types was counted on the basis of the APS [2] timetable and the roadmap.

Table 1: Pairwise correlation matrix analyzing the measurements (number of vehicles).

\begin{tabular}{|l|c|c|c|c|c|}
\hline & HCVs & LCVs & Motorcycles & Passenger cars & Urban buses \\
\hline HCVs & 1 & -.35 & -.51 & .99 & -.62 \\
\hline LCVs & -.35 & 1 & .89 & -.4 & .66 \\
\hline Motorcycles & -.51 & .89 & 1 & -.55 & .79 \\
\hline Passenger cars & .99 & -.40 & -.55 & 1 & -.70 \\
\hline Urban buses & -.62 & .669 & .79 & -.67 & 1 \\
\hline
\end{tabular}

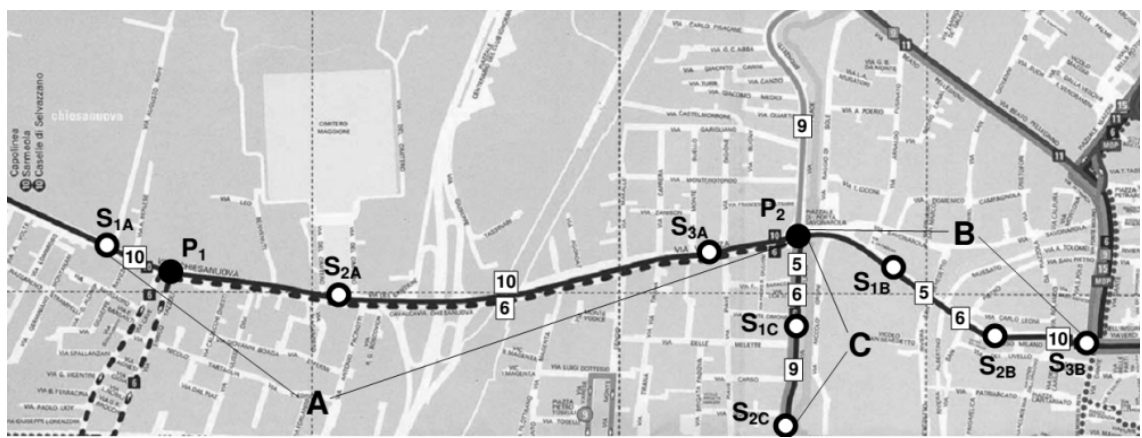

Figure 1: Bus routes in the area of Chiesanuova (street sections $\mathrm{A}, \mathrm{B}, \mathrm{C}$ ); number 5, 6, 9, 10; bus stops: $\mathrm{S}_{1 \mathrm{~A}}, \mathrm{~S}_{3 \mathrm{~A}}, \mathrm{~S}_{1 \mathrm{~B}}, \mathrm{~S}_{3 \mathrm{~B}}, \mathrm{~S}_{1 \mathrm{C}}, \mathrm{S}_{2 \mathrm{C}}$; cross points: $\mathrm{P}_{1}, \mathrm{P}_{2}$.

Table 2: Data of the examined street sections.

\begin{tabular}{|c|c|c|c|}
\hline Section & Route subdivision & Bus route & Bus/day $\left(^{*}\right)$ \\
\hline \multirow{2}{*}{ A } & $\begin{array}{l}\text { S1A-S2A: } 1.3 \mathrm{~km} \\
\text { S2A-S3A: } 2.5 \mathrm{~km} \\
\text { S3A-P2: } 0.35 \mathrm{~km}\end{array}$ & 10 & 185 \\
\hline & $\begin{array}{c}\text { P1-S2A: } 1 \mathrm{~km} \\
\text { S2A-S3A: } 2.5 \mathrm{~km} \\
\text { S3A-P2: } 0.35 \mathrm{~km}\end{array}$ & 6 & 57 \\
\hline B & $\begin{array}{l}\text { P2-S1B: } 0.35 \mathrm{~km} \\
\text { S1B-S2B: } 0.4 \mathrm{~km} \\
\text { S2B-S3B: } 0.3 \mathrm{~km}\end{array}$ & $5-6-10$ & $79-114-185$ \\
\hline $\mathrm{C}$ & $\begin{array}{c}\text { P2-S1C: } 0.4 \mathrm{~km} \\
\text { S1C-S2C: } 0.3 \mathrm{~km}\end{array}$ & $5-6-9$ & $79-57-118$ \\
\hline
\end{tabular}

(*): Both directions 
In order to evaluate the influence on bus operation due to the presence of different types of vehicles, a statistical analysis is carried out using data on emission levels published by the ARPAV [1], a pairwise correlation matrix for six street sections within Chiesanuova (see Table 1). In the pairwise correlation matrix, each cell represents the correlation coefficient denoted by $r$ and calculated over all the available data, which measures the degree of linear relationship between the two variables involved. The results reported in Table 1 show that the number of urban buses is highly correlated with all types of vehicles, primarily with the number of motorcycles and private cars.

As displayed by Figure 2, section A shows a relevant increase in the total number of vehicles with a corresponding decrease in the average vehicle speed in 2005. Interestingly, the average speed in 2005 is remarkably lower than that in 2002, even if the increase in traffic densities is minor; this indicates that, in addition to the number of vehicles, other factors also matter (e.g. road conditions, as the overpass in section A, impact on medium speed (Data concerning the number of vehicles are gained by the Municipality of Padua)).

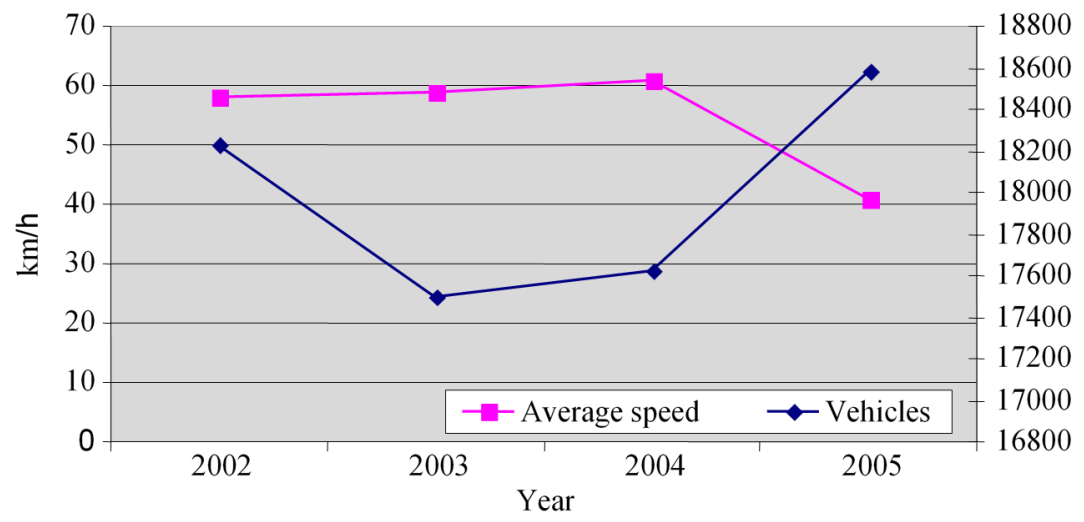

Figure 2: Daily number of vehicles and average speed in section A (20022005).

The lowest emission levels can be observed in streets characterized by "flowing traffic" in Padua to be considered by traffic planners when deciding on public transport policies in Chiesanuova (see, also Amrusch [8]). This shows that under constant road conditions in Chiesanuova, however, public policy will have to focus on improvements in public bus transport in this area, as no alternative infrastructural solutions (e.g. the amplification of the tram network) are planned. This analysis (displayed by Table 1 and Figure 2) seem to accentuate the importance of public bus transport in Chiesanuova also due to the possibility of substitution of private for public transport in future, as the decrease in the average speed along with the increase in air pollution is primarily attributed to the increase in private car use. 


\section{Data analysis and emission estimation}

On the basis of European emission standards, the fleet of buses maintained by the APS [2] (Figure 3(a)) is composed by environmentally friendly models (e.g. methane-run buses meeting the EURO IV emission standards) and buses equipped with EURO III, II and I standard engines - running on dual-fuel or diesel. Other than on Sundays - when only ecological bus types are used - during the week bus types are randomly chosen for different bus routes in Padua, whereas during peak traffic hours all types of vehicles are used. As a consequence, the investigation focuses on emissions produced by public transport during the week.
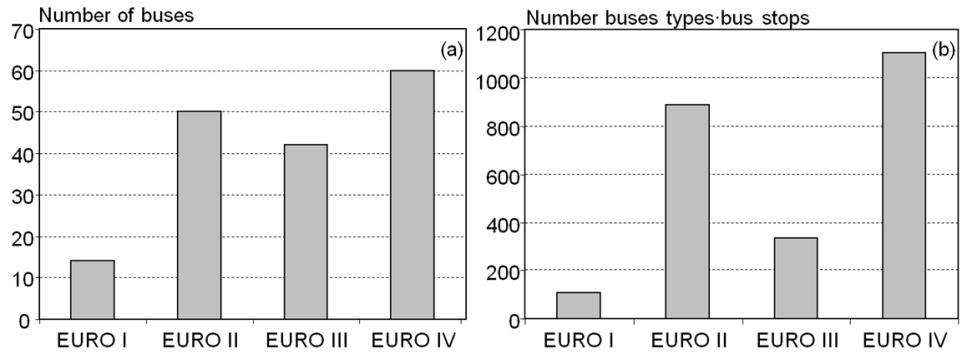

Figure 3: (a) Classification of the main part of the APS [2] fleet based on emission standards; (b) total number of buses per day in Chiesanuova, subdivided according to their emission standards.

By using the software program COPERT III [3], emission factors are calculated for all daily operating types of buses. The calculation of emissions requires a prior detailed classification of all types of buses operating in the street sections A, B and $\mathrm{C}$ regarding emission classification standards as well as the estimation of the average speeds of buses with respect to the distances between two subsequent bus stops as further input data. To consider the lengths of each bus route along with the quantity of buses daily operating on a route the number of buses is multiplied by the number of distances between any two corresponding bus stops and cross points (see Figure 1 and Table 2), obtaining the value of 2368 observations related to the weights of bus models and emission standards used in Chiesanuova.

As the rolling stock of bus models used by the APS [2] was larger than the number of daily employed buses in 2006, all buses (exclusively the bus line 10 merely running on methane (Euro IV)) were first weighted according to the emission standards classification (EURO I (9\%), II (73\%), III (18\%)) and then buses (Euro I, II, III, IV) were weighted according to bus models maintained by the APS (e.g. differing in length, kilowatts, cubic capacity and engine power) within emission standard classifications.

Thereby, buses such as, minibuses or "extra-urban" buses, which were not used at all in section A, B and C, in 2006, were a priori excluded. Figure 3(b) shows that buses running on methane (Euro IV) were predominantly used in street sections $\mathrm{A}, \mathrm{B}$ and $\mathrm{C}$, whereby the vertical axis represents the number of buses with respect to the number of the corresponding bus stops. 
On the other hand, in our sample around $48 \%$ are diesel-run and $46 \%$ are methane-run, whereas the remaining percentage is dual-fuel run.

As bus speed varies according to the bus stop distance and road characteristics (traffic rules, traffic densities etc.), particulate matters are calculated for all daily bus runs (see Table 2) between two bus stops, considering that buses are bidirectional. Since traffic emissions also vary according to the speed of buses, by using the software program COPERT III [3], (hot stabilized) CO and $\mathrm{PM}_{10}$ emission factors per bus, $\mathrm{e}_{\mathrm{pm}}$, expressed in $\mathrm{g} / \mathrm{km}$ (see Table 3 ), are estimated with respect to all daily-travelling urban bus types and operating distances between two bus stops, denoted by $\mathrm{d}$, on the predetermined bus routes, whereby the estimation reflects the measured medium speed (the medium travel time as well as the average speed between two subsequent bus stops are measured during the peak traffic hours in the afternoon on the 12th of June 2006).

Table 3: Emission factors $e$ (PM10 expressed in $\mathrm{g} / \mathrm{km}$ ) with respect to streets sections $\mathrm{A}, \mathrm{B}, \mathrm{C}$, bus stops and average speed (along with the number of buses in parentheses).

\begin{tabular}{|c|c|c|c|c|}
\hline Street section A & $\begin{array}{c}\text { Bus line } 6 \\
\text { Euro I }\end{array}$ & $\begin{array}{c}\text { Bus line } 6 \\
\text { Euro II }\end{array}$ & $\begin{array}{c}\text { Bus line } 6 \\
\text { Euro III }\end{array}$ & $\begin{array}{c}\text { Bus line } 10 \\
\text { Euro IV }\end{array}$ \\
\hline $\begin{array}{l}\text { average speed } \\
S_{1 A}-S_{2 A} \text { or } P_{2}-S_{2 A}\end{array}$ & $\begin{array}{c}25 \mathrm{~km} / \mathrm{h} \\
(\mathrm{N}=5)\end{array}$ & $\begin{array}{c}25 \mathrm{~km} / \mathrm{h} \\
(\mathrm{N}=42)\end{array}$ & $\begin{array}{l}25 \mathrm{~km} / \mathrm{h} \\
(\mathrm{N}=10)\end{array}$ & $\begin{array}{l}25 \mathrm{~km} / \mathrm{h} \\
(\mathrm{N}=185)\end{array}$ \\
\hline $\mathrm{PM}_{10}$ in $\mathrm{g} / \mathbf{k m}$ & .4780 & .2944 & .2059 & .0390 \\
\hline $\begin{array}{l}\text { average speed } \\
S_{2 A}-S_{3 A}\end{array}$ & $\begin{array}{c}15 \mathrm{~km} / \mathrm{h} \\
(\mathrm{N}=5)\end{array}$ & $\begin{array}{l}15 \mathrm{~km} / \mathrm{h} \\
(\mathrm{N}=42)\end{array}$ & $\begin{array}{c}15 k m \\
(N=10)\end{array}$ & $\begin{array}{l}15 \mathrm{~km} / \mathrm{h} \\
(\mathrm{N}=185)\end{array}$ \\
\hline $\mathrm{PM}_{10}$ in $\mathrm{g} / \mathrm{km}$ & .6963 & .4285 & .30 & .0568 \\
\hline $\begin{array}{l}\text { average speed } \\
S_{3 \mathrm{~A}}-\mathrm{P}_{2}\end{array}$ & $\begin{array}{c}28 \mathrm{~km} / \mathrm{h} \\
(\mathrm{N}=5)\end{array}$ & $\begin{array}{c}28 \mathrm{~km} / \mathrm{h} \\
(\mathrm{N}=42)\end{array}$ & $\begin{array}{l}28 \mathrm{~km} / \mathrm{h} \\
(\mathrm{N}=10)\end{array}$ & $\begin{array}{l}28 \mathrm{~km} / \mathrm{h} \\
(\mathrm{N}=185)\end{array}$ \\
\hline $\mathrm{PM}_{10}$ in $\mathrm{g} / \mathbf{k m}$ & .4398 & .2707 & .1895 & .0359 \\
\hline Street section B & $\begin{array}{c}\text { Bus lines 5-6 } \\
\text { Euro I }\end{array}$ & $\begin{array}{c}\text { Bus lines 5-6 } \\
\text { Euro II }\end{array}$ & $\begin{array}{c}\text { Bus lines 5-6 } \\
\text { Euro III }\end{array}$ & $\begin{array}{c}\text { Bus line } 10 \\
\text { Euro IV }\end{array}$ \\
\hline $\begin{array}{l}\text { average speed } \\
\mathrm{P}_{2}-\mathrm{S}_{1 \mathrm{~B}}\end{array}$ & $\begin{array}{c}35 \mathrm{~km} / \mathrm{h} \\
(\mathrm{N}=10+7)\end{array}$ & $\begin{array}{c}35 \mathrm{~km} / \mathbf{h} \\
(\mathrm{N}=83+58)\end{array}$ & $\begin{array}{c}35 \mathrm{~km} / \mathrm{h} \\
(\mathrm{N}=\mathbf{2 1}+14)\end{array}$ & $\begin{array}{l}35 \mathrm{~km} / \mathrm{h} \\
(\mathrm{N}=185)\end{array}$ \\
\hline $\mathrm{PM}_{10}$ in $\mathrm{g} / \mathrm{km}$ & .3732 & .230 & .1608 & .0304 \\
\hline $\begin{array}{l}\text { average speed } \\
S_{1 B}-S_{2 B}\end{array}$ & $\begin{array}{c}30 \mathrm{~km} / \mathrm{h} \\
(\mathrm{N}=10+7)\end{array}$ & $\begin{array}{c}30 \mathrm{~km} / \mathrm{h} \\
(\mathrm{N}=83+58)\end{array}$ & $\begin{array}{c}30 \mathrm{~km} / \mathrm{h} \\
(\mathrm{N}=21+14)\end{array}$ & $\begin{array}{l}30 \mathrm{~km} / \mathrm{h} \\
(\mathrm{N}=185)\end{array}$ \\
\hline $\mathrm{PM}_{10}$ in $\mathrm{g} / \mathrm{km}$ & .4180 & .2573 & .1801 & .0341 \\
\hline $\begin{array}{l}\text { average speed } \\
S_{2 B}-S_{3 B}\end{array}$ & $\begin{array}{c}20 \mathrm{~km} / \mathrm{h} \\
(\mathrm{N}=10+7)\end{array}$ & $\begin{array}{c}20 \mathrm{~km} / \mathrm{h} \\
(\mathrm{N}=83+58)\end{array}$ & $\begin{array}{c}20 \mathrm{~km} / \mathrm{h} \\
(\mathrm{N}=21+14)\end{array}$ & $\begin{array}{l}20 \mathrm{~km} / \mathrm{h} \\
(\mathrm{N}=185)\end{array}$ \\
\hline $\mathrm{PM}_{10}$ in $\mathrm{g} / \mathbf{k m}$ & .5634 & .3467 & .2427 & .0459 \\
\hline Bus routes 9, 6, 5 & $\begin{array}{c}\text { Bus lines 5-6-9 } \\
\text { Euro I }\end{array}$ & $\begin{array}{c}\text { Bus lines 5-6-9 } \\
\text { Euro II }\end{array}$ & $\begin{array}{c}\text { Bus lines 5-6-9 } \\
\text { Euro III }\end{array}$ & \\
\hline $\begin{array}{l}\text { average speed } \\
\mathrm{P}_{2}-\mathrm{S}_{1 \mathrm{C}}\end{array}$ & $\begin{array}{c}18 \mathrm{~km} / \mathrm{h} \\
(\mathrm{N}=5+7+11)\end{array}$ & $\begin{array}{c}18 \mathrm{~km} / \mathrm{h} \\
(\mathrm{N}=42+58+86)\end{array}$ & $\begin{array}{c}18 \mathrm{~km} / \mathrm{h} \\
(\mathrm{N}=10+14+21)\end{array}$ & \\
\hline $\mathrm{PM}_{10}$ in $\mathrm{g} / \mathrm{km}$ & .6088 & .3747 & .2623 & \\
\hline $\begin{array}{l}\text { average speed } \\
S_{1 C}-S_{2 C}\end{array}$ & $\begin{array}{c}18 \mathrm{~km} / \mathrm{h} \\
(\mathrm{N}=5+7+11)\end{array}$ & $\begin{array}{c}18 \mathrm{~km} / \mathrm{h} \\
(\mathrm{N}=42+58+86)\end{array}$ & $\begin{array}{c}18 \mathrm{~km} / \mathrm{h} \\
(\mathrm{N}=10+14+21)\end{array}$ & \\
\hline $\mathrm{PM}_{10}$ in $\mathrm{g} / \mathbf{k m}$ & .6088 & .3747 & .2623 & \\
\hline
\end{tabular}


Calculating the total daily PM10 emissions by

$$
e_{P M}=\sum_{1}^{n_{b u s}} P M \cdot d
$$

in street section $\mathrm{A}$, the value $\mathrm{e}_{\mathrm{PM}}=121 \mathrm{~g}$ is estimated, whereas in section $\mathrm{B}$ and $\mathrm{C}$ the quantities of particulate matters amount to $\mathrm{e}_{\mathrm{PM}}=62 \mathrm{~g}$ and $\mathrm{e}_{\mathrm{PM}}=67 \mathrm{~g}$ per day, respectively (Eq. (1)). Considering that the number of total daily runs per distance between any two bus stops in section A, B and C add up to 726, 1134 and 508, respectively, and that the investigated street sections $\mathrm{A}, \mathrm{B}$ and $\mathrm{C}$, are $4.15 \mathrm{~km}$, $1.05 \mathrm{~km}$ and $0.7 \mathrm{~km}$ in length, respectively, $\mathrm{PM}_{10}$ come to $29 \mathrm{~g} / \mathrm{km}$ in section $\mathrm{A}$, $59 \mathrm{~g} / \mathrm{km}$ in section $\mathrm{B}$ and $96 \mathrm{~g} / \mathrm{km}$ in section C.

The lowest value in section A may be attributed to the fact that, in this section, the largest percentage of methane-run buses $(76 \%)$ circulate - 185 methane-run buses daily contribute to a total of $24 \mathrm{~g}$ of $\mathrm{PM}_{10}$ - whereas 57 diesel- $(21 \%)$ and dual-fuel-run buses $(3 \%)$ produce about $39 \mathrm{~g}$ of $\mathrm{PM}_{10}$, respectively. In section $\mathrm{B}$ the proportion of buses running on methane amounts to $49 \%$, whereas in section $\mathrm{C}$ only diesel and dual-fuel-run buses circulate.

\section{Environmental impact of public transport policies}

\subsection{Environmental quantification of the employment of methane-run buses in Chiesanuova}

Technically, substituting all diesel- and dual-fuel-run buses for methane buses under the same traffic conditions in sections A, B, C, total daily particulate matter emissions produced by public transport would be reduced by $72 \mathrm{~g}, 48 \mathrm{~g}$ and $58 \mathrm{~g}$, respectively (see Figure 4). In other words, the use of exclusively methane-runbuses in Chiesanuova would decrease emission factors by about $0.02 \mathrm{~g} / \mathrm{km}$ in section $\mathrm{A}, 0.06 \mathrm{~g} / \mathrm{km}$ in section $\mathrm{B}$ and $0.07 \mathrm{~g} / \mathrm{km}$ in section $\mathrm{C}$.

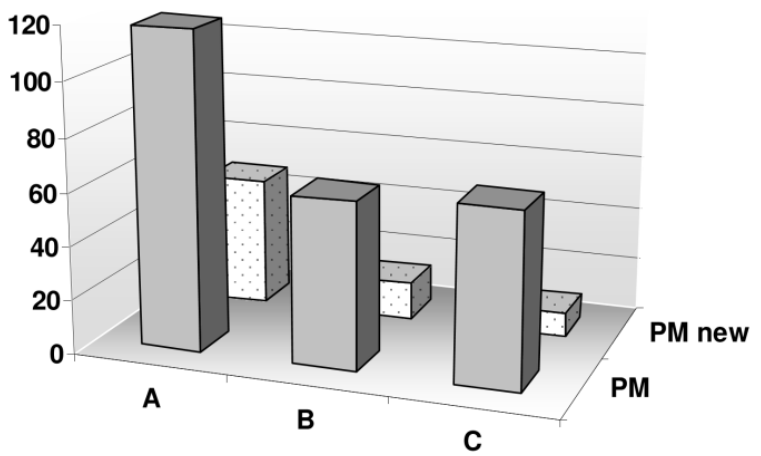

Figure 4: Particulate matters reduction after switching to methane-run buses.

Contrarily, replacing all existing methane-run buses by buses of Euro I; II and III emission standards (according to the above-mentioned weights) we can 
separate out the effect of methane-run buses in Chiesanuova in 2006: methane-run buses reduce emissions by $61 \%$ in section $\mathrm{A}, \mathrm{B}$ and $\mathrm{C}$.

More precisely, in section $\mathrm{A}$, methane-run buses decrease particulate matters by $34 \%$, whereas in section $\mathrm{B}$ the decrease is $58 \%$.

Alternatively, one can use the technical model to generate (pseudo) data (instead or as a substitute for direct measurements), and to use this data as the basis for statistical analysis in order to obtain reduced form relations; this method was pioneered by Griffin $[4,5]$.

The choice of functional form is based on theoretical considerations (the linear relationship between relevant variables, such as emissions and medium speed).

Using the method of Ordinary Least Squares, the regression for the whole sample (section A, B, C ( $\mathrm{N}=2368)$ ) is given in Table 4 (1-3 and 7) along with the absolute $t$-statistics in parentheses explaining the variation of bus attributes and environmental characteristics in $\mathrm{g} / \mathrm{km}$ particulate matters. Since buses are considered aggregations of attributes (as cylinder, power, etc.), regression based on pseudo data relates the particulate matters (PM) (2) or carbon monoxide (CO) (1) as well as concentrations of $\mathrm{PM}_{2.5}$ (C2.5) (7) emitted by a bus, to its attributes. However, as emission standards are related to bus attributes, the variation in emissions is mainly explained by emission standards. The dummy variable Euro 4 takes on the value 1 for methane-run buses and zero otherwise, while the dummy variable Euro123 describes Euro I, Euro II and Euro III, which take on the values 1,2 and 3 , respectively.

Table 4: Regression analyses.

\begin{tabular}{|c|c|c|c|c|c|c|c|}
\hline Coeff. \& C & $\begin{array}{c}A, B, C \\
(1)\end{array}$ & $\begin{array}{c}\text { A, B. C } \\
(2)\end{array}$ & $\begin{array}{c}\mathrm{A}, \mathrm{B}, \mathrm{C} \\
(3)\end{array}$ & $\begin{array}{c}\text { A } \\
(4) \\
\end{array}$ & $\begin{array}{c}\text { B } \\
(5) \\
\end{array}$ & $\begin{array}{c}\mathrm{C} \\
(6) \\
\end{array}$ & $\begin{array}{c}A, B, C \\
(7)\end{array}$ \\
\hline $\mathrm{C}$ & $\begin{array}{c}2.16 \\
(310.9)\end{array}$ & $\begin{array}{c}.44 \\
(56.5)\end{array}$ & $\begin{array}{c}4.47 \\
(903.7)\end{array}$ & $\begin{array}{c}.46 \\
(23.6)\end{array}$ & $\begin{array}{c}.447 \\
(38.5)\end{array}$ & $\begin{array}{c}-.17 \\
(15.15)\end{array}$ & $\begin{array}{l}-8.058 \\
(620.6)\end{array}$ \\
\hline Methane-run & $\begin{array}{c}1.27 \\
(194.0)\end{array}$ & $\begin{array}{c}-2.82 \\
(391.2)\end{array}$ & $\begin{array}{l}-.14 \\
(28.0)\end{array}$ & $\begin{array}{c}-2.77 \\
(145.4)\end{array}$ & $\begin{array}{l}-2.871 \\
(295.1)\end{array}$ & & $\begin{array}{l}-1.973 \\
(309.9)\end{array}$ \\
\hline M_kmh & $\begin{array}{c}-.03 \\
(278.4)\end{array}$ & $\begin{array}{c}-.03 \\
(199.3)\end{array}$ & & $\begin{array}{c}-.03 \\
(164.1)\end{array}$ & $\begin{array}{c}-.032 \\
(126.9)\end{array}$ & & $\begin{array}{l}-.033 \\
(66.1)\end{array}$ \\
\hline Euro123 & $\begin{array}{c}-.31 \\
(104.4)\end{array}$ & $\begin{array}{c}-.40 \\
(129.5)\end{array}$ & $\begin{array}{c}-.02 \\
(11.1)\end{array}$ & $\begin{array}{l}-.40 \\
(46.9)\end{array}$ & $\begin{array}{l}-.405 \\
(97.9)\end{array}$ & $\begin{array}{c}-.40 \\
(79.87)\end{array}$ & \\
\hline KW & & & $\begin{array}{c}.00018 \\
(3.1)\end{array}$ & & & & \\
\hline Weight & & & $\begin{array}{c}.00016 \\
(4.7) \\
\end{array}$ & & & & \\
\hline $\mathrm{R}^{2}$ & .99 & .99 & .73 & .99 & .99 & .97 & .98 \\
\hline Adj. $R^{2}$ & .99 & .99 & .73 & .99 & .99 & .97 & .98 \\
\hline F-statistic & 271612 & 257550 & 1575 & 102895 & 101384 & 19655 & 49684 \\
\hline Incl. obs. & 2368 & 2368 & 2368 & 726 & 1134 & 508 & 2368 \\
\hline Dep. var. & $\log (\mathrm{CO})$ & $\log (\mathrm{PM})$ & $\log (\mathrm{DB})$ & $\log (\mathrm{PM})$ & $\log (\mathrm{PM})$ & $\log (\mathrm{PM})$ & $\log (\mathrm{C} 2.5)$ \\
\hline
\end{tabular}

Including only highly significant coefficients, regressions $(2,4,5)$ display the strong impact of methane-run buses on the emitted particulate matters (PM) in $\mathrm{g} / \mathrm{km}$ in Chiesanuova (section A, B, C) as well as A and B, showing a 282\%, 277\% and $287 \%$ particulate matters reduction. Regression (7) explains a $197 \%$ decrease 
in $\mathrm{PM}_{2.5}$ concentrations due to methane-bus operations. It should be mentioned that other functional form specifications (e.g. lin-lin) also give similar results, which extremely overvalue the technical results. As expected, the medium speed (medium $\mathrm{km} / \mathrm{h}$ ) is negatively correlated with all emissions in all regressions: if the bus speed increases by $1 \mathrm{~km} / \mathrm{h}$, emissions decrease by about $3 \%$. It is to be considered that, although in section A the highest percentage of methane-run buses operate, in section A, the measured speed is lower than that in section B (presumably due to an overpass), increasing overall emission levels in section A. (Technically, the optimal speed, with respect to the level of particulate matters and fuel consumptions, of methane buses is considerably over $130 \mathrm{~km} / \mathrm{h}$, exceeding the speed limits on highways - which also is not feasible due to the bus stop distance, security issues and legal speed limits or traffic conditions related to private transport). Interestingly, upgrading the bus in terms of European emission standards reduces emissions by about $40 \%$ in section $\mathrm{C}(6)$, where no methane buses at all circulate - similar to sections B (5) and A (4).

Considering that the market price for methane was also lower than that of diesel in 2006, the utilization of methane-run buses allows substantial cost savings relevant for economic and efficiency considerations (APS [2]). Regression (3) provides evidence that the noise level (given in decibel) of a bus is negatively correlated with methane-run buses with possible impacts on health costs.

\subsection{Social and economic impacts of the employment of methane-run buses in Chiesanuova}

The monetary quantification of transport emissions could be done by environmental valuation methods (such as the hedonic pricing model or the contingent valuation method (CV)) aiming at measuring individual preferences. Contrary to the $\mathrm{CV}$ method based on the concept of stated preference, using the hedonic method (formalized by Rosen [9] and Freeman [10]) in the context of air pollution) the individual willingness-to-pay is revealed by choices in the market [11]. A study conducted by the WHO [6] shows that Padua is among the Italian cities risking higher mortality and morbidity rates due to the concentration of particulates with 202 work loss days (WLD) per $10-\mu \mathrm{g} / \mathrm{m}^{3}$ increment in $\mathrm{PM}_{2.5}$ concentration per year (city-specific impact functions were derived per 1000 people 15-64 years of age in the general population) per 1000 people per year.

An approximation of social health costs of PM in Chiesanuova based on WHO [6], for substituting gasoline- for methane-run buses (up to 20 meters in distance from roads), is calculated by using a basic dispersion curve formula, evaluating the maximum concentration in $\mu \mathrm{g} / \mathrm{m}^{3}$ of the $\mathrm{X}$ pollutant as:

$$
\mathrm{X}=0.325 \exp \left(-0.3 \mathrm{~d}^{0.5}\right) *(\mathrm{~N} / \mathrm{T}) * \mathrm{EF}
$$

with $\mathrm{d}$ distance from roadside in meters, $\mathrm{T}$ time period assessed (1-24 hours), $\mathrm{N}$ number of vehicles in the period $T$ and EF emission factor in $\mathrm{g} / \mathrm{km}$. Eq. (2) is applied by, e.g., Ministry of the Environment of Manatū Mō Te Taiao [12].

For $\mathrm{N} / \mathrm{T}=1 / 18$ (assessing the concentration per run between two bus stops per bus within 18 hours, since for 6 hours during the night a negligibly small number of buses operates), the $\mathrm{PM}_{10}$ concentrations (in $\mu \mathrm{g} / \mathrm{m}^{3}$ ) are obtained for the total 
number of buses per bus stop distance travelled (commensurate with the weighted averages for Euro I, II and III calculated above), European emission standards classification and medium speed. Summarizing all PM concentration ratios in $\mu \mathrm{g} / \mathrm{m}^{3}$, public transport emits a daily concentration of $2 \mu \mathrm{g} / \mathrm{m}^{3}$ of $\mathrm{PM}_{10}$ (or $\mu \mathrm{g} / \mathrm{m}^{3}$ 1.5 of $\mathrm{PM}_{2.5}$ [13]) within a distance of 20 meters from the roadside in sections $\mathrm{A}$, $\mathrm{B}$ and $\mathrm{C}$. The substitution of diesel- and dual-fuel-run for methane-run buses reduces the overall $\mathrm{PM}_{10}$ concentration to $.47 \mu \mathrm{g} / \mathrm{m}^{3} \mathrm{PM}_{10}$ (or $0.3265 \mu \mathrm{g} / \mathrm{m}^{3}$ of $\mathrm{PM}_{2.5}$, by applying the same conversion factor of 0.7 used by WHO [6]: $0.7 * \mathrm{PM}_{10}$ $=\mathrm{PM}_{2.5}$ ). A $76 \%$ reduction in emission concentrations is substantial. Seeing that WHO [6] shows that in Padua an increase in $10 \mu \mathrm{g} / \mathrm{m}^{3}$ of PM corresponds to 202 work loss days per 1000 people per year, in the residential areas near the street sections A, B and C, 31 work loss days are saved per 1000 people per year. For future research a detailed comparison of social costs attributed to private transport and public transport could be undertaken - in particular with respect to possible substitution effects of private for public transport. Moreover, in addition to the benefits for social welfare, the potential long-term cost savings for transportation companies, as APS [2], due to efficiency improvements using methane-run buses instead of more conventional fuel technologies could be evaluated.

\section{Conclusion}

Based on current public policy debates related to the public urban transport system in Padua, this paper first shows technically the impact of urban buses differing in emission standards and types of fuel, in particular methane-run buses, on particulate matters in a critical urban environment using generated data. Afterwards, a pseudo-data approach is applied to quantify the environmental impact of the exclusive introduction of methane-run buses, allowing for a detailed comparison of these two approaches. Finally, based on studies of economic and social quantification of traffic emissions with special emphasis on Padua, the social and health consequences of the exclusive use of methane-run buses in Chiesanuova are monetarily quantified and analyzed.

Empirical results show that higher European emission standards - in particular the use of methane-run buses - substantially reduce particulate matters in Chiesanuova, which is of particular importance, as in this area no tram construction is planned as a matter of public policy. The substantial air quality improvement as a consequence of use of methane-run buses also improves social welfare in monetary terms.

Of additional interest for traffic planners is the fact that the medium speed has a negative impact on emissions (as investigated in the introductory section), emphasizing the importance of keeping traffic flowing. Seeing that, in addition to the employment of methane-run buses in Chiesanuova, vehicle reduction (see introductory part) should be promoted (especially with respect to private transport). As traffic conditions also influence medium speed, the improvement of infrastructural road conditions in combination with vehicle reduction should be promoted for a constant medium velocity, thus improving air quality relevant for 
human health and other economic reasons as well as natural harmony in Chiesanuova.

\section{Acknowledgements}

Special acknowledgment to APS [2], ARPAV [1], the Municipality of Padua, B. Böhm, F. Mitis (WHO), and others.

\section{References}

[1] ARPAV Agenzia Regionale per la Prevenzione e Protezione Ambientale del Veneto. Rapporto annuale 2002, La qualità dell'aria nel comune di Padova, ARPAV, 2002.

[2] APS Azienda Padova Servizi, Terza fermata: Ambiente, energia e risorse. Social Accounting Report, APS: www.aps.it, 2004.

[3] COPERT III (http://lat.eng.auth.gr/copert/)

[4] Griffin, J.M., Long-run production modelling with pseudo data: electric power generation, Bell Journal of Economics 8(1), pp. 112-127, 1977a.

[5] Griffin, J.M., The Econometrics of Joint Production: Another Approach, The Review of Economics and Statistics 59(4), pp. 389-397, 1977b.

[6] WHO: Martuzzi $\mathrm{M}$ et al., Health impact of $\mathrm{PM}_{10}$ and ozone in 13 Italian cities World Health Organization. Regional office for Europe www.euro.who.int/document/e88700.pdf, 2006.

[7] Andriollo, M. et al., Innovative technologies for the public transportation in the Urban Mobility Plan of Padova, in Proc. of the Int. Conf. on Urban Transport and the Environment, Brebbia et al. (eds.), WIT Press, UK., pp. 75-88, 2002.

[8] Amrusch, P., The impact of urban traffic and environmental factors on the housing market: An analysis of the Italian and Slovenian urban areas, in Proc. of the Int. Conf. on Urban Transport and the Environment, Brebbia, CR and Wadhwa, L (eds.), WIT Press, UK, pp. 807-813, 2005.

[9] Rosen, S., Hedonic Prices and Implicit Markets: Product Differentiation in Pure Competition, Journal of Political Economy 82, pp. 34-55, 1974.

[10] Freeman III, A.M., On Estimating Air Pollution Control Benefits from Land Value Studies, Journal of Environmental Economics and Management 1(1), pp. 74-83, 1994.

[11] Garrod, G., Willis, K.G. Economic Valuation of the Environment, Cheltenham: Edward Elgar Publishing, 1999.

[12] Ministry for the Environment Manatū Mō Te Taiao, prepared by the National Institute of Water and Atmospheric Research, Aurora Pacific Limited and Earth Tech Incorporated for the Ministry for the Environment, Good Practice Guide for Atmospheric Dispersion Modelling, Ministry for the Env. Manatū Mō Te Taiao, New Zealand www.mfe.govt.nz, 2004.

[13] Bluett, J., Fisher, G.W., Validation of a vehicle emissions model using onroad emissions measurements, in Hobart May (ed.) Proc. of the Clean Air and Environment 17th Annual Conference, Clean Air Society of Australia and New Zealand. www.casanz.org.au, 2005. 